\title{
Headache symptoms of the PREEMPT population
}

\author{
DW Dodick ${ }^{*}$, RE DeGryse ${ }^{2}$, CC Turkel $^{2}$ \\ From The European Headache and Migraine Trust International Congress \\ London, UK. 20-23 September 2012
}

\section{Introduction}

$\mathrm{CM}$ is a complex neurological disorder affecting approximately $2 \%$ of the general adult population. CM sufferers experience a broad range of debilitating symptoms.

\section{Objective}

To assess the daily headache symptoms of chronic migraine $(\mathrm{CM})$ patients over a 4-week period.

\section{Design/methods}

PREEMPT (two phase 3 studies: 24-week, double-blind, placebo-controlled, parallel-group phase, followed by $32-$ week, open-label phase) evaluated onabotulinumtoxinA for prophylaxis of headaches in CM ( $>15$ days/month with headache lasting $>4$ hours/day). A total of 1384 $\mathrm{CM}$ patients daily reported their headache symptoms for a 28-day baseline period using an interactive voice response telephone diary. The baseline frequencies of various headache features and associated symptoms were computed.

\section{Results}

Of 38,752 total days, patients reported 27,483 (70.9\%) days with $>4$ hours of headache. Patients classified their pain as moderate/severe on $90.9 \%$ of their headachedays. The most common associated symptoms patients described experiencing on headache-days were photophobia (81.2\%), phonophobia (80.2\%), exacerbation with physical activity (80.0\%), pulsating quality (70.8\%), unilateral pain $(63.6 \%)$, and nausea (59.8\%). Vomiting $(13.8 \%)$ was reported infrequently.

\section{Conclusion/relevance}

These CM patients experienced severe headache symptoms throughout the 28-day baseline period. The overwhelming majority of headaches were characterized as moderate/severe pain intensity, which were often

${ }^{1}$ Mayo Clinic Arizona, Dept. of Neurology, Phoenix, AZ, United States, USA Full list of author information is available at the end of the article accompanied with sensitivity to both light and sound and aggravated by routine physical activity. The majority of patients also reported pulsating pain quality, unilateral headache, and nausea. The heavy burden of illness suffered by CM patients emphasizes the necessity of prophylactic treatment for their headaches.

\section{Support}

Allergan, Inc.

\section{Author details}

${ }^{1}$ Mayo Clinic Arizona, Dept. of Neurology, Phoenix, AZ, United States, USA. ${ }^{2}$ Allergan, Irvine, CA, United States, USA.

Published: 21 February 2013

doi:10.1186/1129-2377-14-S1-P99

Cite this article as: Dodick et al:: Headache symptoms of the PREEMPT population. The Journal of Headache and Pain 2013 14(Suppl 1):P99. (c) 2013 Dodick et al; licensee Springer. This is an Open Access article distributed under the terms of the Creative Commons Attribution License (http://creativecommons.org/licenses/by/2.0), which permits unrestricted use, distribution, and reproduction in any medium, provided the original work is properly cited.
Submit your manuscript to a SpringerOpen ${ }^{\circ}$ journal and benefit from:

- Convenient online submission

- Rigorous peer review

- Immediate publication on acceptance

- Open access: articles freely available online

- High visibility within the field

- Retaining the copyright to your article

Submit your next manuscript at $\boldsymbol{s p r i n g e r o p e n . c o m ~}$ 